\title{
MARKET ACCESS AND THE EVOLUTION OF WITHIN PlANT PRODUCTIVITY IN CHILE
}

\author{
MARIA BAS \\ IVAN LEDEZMA
}

\section{CESIFO WORKING PAPER NO. 2077 \\ CATEgORY 7: TRAde Policy \\ August 2007}

Presented At CESifo Venice SuMmer InSTITUTE, WORKSHOP ON

'The ECONOMics of Aggregate SHOCKS In HeterogenOUS FIRM MODELS', July 2007

\footnotetext{
An electronic version of the paper may be downloaded

- from the SSRN website: Www.SSRN.com

- from the RePEc website: $\quad$ www.RePEc.org

- from the CESifo website: www.CESifo-group.org/wp
} 


\title{
MARKET ACCESS AND THE EVOLUTION OF WITHIN PLANT PRODUCTIVITY IN CHILE
}

\begin{abstract}
This paper studies the impact of trade reforms on the evolution of plant's productivity in Chile (1979-2000). The main contribution of the paper is to construct detailed measures of trade liberalization disentangling the impact of export and import oriented policies. We find evidence of a positive impact of export oriented policies on productivity of traded sectors relative to non traded. On the other hand, the reduction of import barriers might have a positive impact on productivity in export oriented sectors, but it hurts local firms in import competing ones probably due to the existence of increasing returns.
\end{abstract}

JEL Code: F10, F12, F41.

Keywords: firm heterogeneity, trade reforms, productivity gains, plant's panel data.

Maria Bas
Pse-Ens
48 bd Jourdan
75014 Paris
France
bas@pse.ens.fr

Maria Bas

48 bd Jourdan

France

bas@pse.ens.fr 


\section{Introduction}

Trade liberalization was at the core of reform packages implemented in many developing economies during 1980's. Several empirical works have found evidence of a positive correlation between trade liberalization and productivity both at aggregated and plant's level (see Pavcnik (2002), Bernard and Jensen (2001), Clerides et al. (1998), Bernard, Jensen and Schott (2003)). In this paper we revisit the case of Chile, one of the earliest and most radical examples of trade liberalization in developing countries. We aim at testing the link between this reform and productivity in Chilean manufacturing plants. To test this relationship we first estimate plant's TFP taking into account firm heterogeneity in terms of productivity levels and then estimate the impact of market access on plant's productivity. To do so we use the anual industry ENIA survey (encuesta anual industrial) of manufacturing Chilean's plants and the Trade and Production database provided by CEPII (centre d'etudes prospecives et d'information internationalles).

Our contribution to previous works is to disentangle policy implications on both export and import sides. We construct a measure of trade liberalization which takes into account the evolution of market access over time and across industries between Chile and its main trading partners. These measures, usually referred as "border effects", essentially capture trade difficulties from the fact of crossing national border and selling or buying abroad. Considering only tariffs or year dummies may neglect two important features of trade policy. First, unilateral import tariff reduction may not be symmetric among trade partners. Second, the role of non tariffs barriers, fixed export costs and bilateral agreements may be an important determinant of trade flows. Taking into account the evolution of market access allow us identifying which industries benefit the most, in terms of productivity gains, from import or export oriented policies.

Arguments concerning the consequences of trade liberalization do not always go in the same direction. Foreign competition is usually highlighted as a positive engine of productivity. It would press less productive firms to exit the market and surviving firms to trim their inefficiencies. However, the presence of increasing returns to scale (IRS) and imperfect competition may introduce new ingredients to the model (Devarajan and Rodrik (1999), Rodrik (1992)). In particular one of the most important features of the Krugman (1980) model of economies of scales is precisely that average cost falls as output increases. In that sense, the size of local market plays an important role mapping cost structures. The monopoly power means that 
firms integrate their demand in their decisions and so the advantage of price setting ${ }^{1}$. In a country like Chile, with a population nowadays of 16 million (11 million in the 1982 census), the opportunities for scales economies in import competing sectors after a radical change in foreign market competition are likely constrained. On the empirical grounds, Antweler and Trefler (2002) show that indeed scales economies do matter to explain trade patterns.

The literature also suggests learning by exporting as a plausible mechanism to explain the effects of trade liberalization on plant's productivity. Several empirical works find evidence of ex post increasing productivity gains arising from selling in foreign markets (See Aw, Chung, Roberts (1999) for Korea, Kray (1999) for Chinese firms, and Alvarez and Lopez (2005) for Chile). The undermining theoretical channel focuses on productivity improvements resulting from knowledge and expertise gained in the export process. One possible explanation is that exporters learn from their contacts in the export market, and as a result they adopt better production methods and achieve higher productivity. Clerides, Lach and Tybout (1998) construct a dynamic model based on Baldwin (1989), Dixit (1989) and Krugman (1989). In their model firm's current productivity depends on prior export experience. As a result, learning by exporting widens the gap between the productivity of firms that enter the export market and those that sell only to the domestic market. Related to this view Grossman and Helpman (1991) develop a trade and innovation model emphasizing the role of international spillovers in the growth process. By disentangling the nature of trade policies, using specific export and import oriented policies, We might capture benefits stemming from this mechanism.

Chilean dictatorship in power from 1973 to 1990, implemented a deep package of market reforms concerning every economic field. Among them trade liberalization took place in the second half of seventies. Since the beginning of the period, all trade barriers and restrictions to trade were removed. Average nominal tariff rates decreased gradually from $98 \%$ in 1973 to $10 \%$ in 1979 . Specially, during nineties one of the main trade strategies of Chile was to pursuing several trade agreements with different countries and regions, without being tied to only one regional customs unions. Chile has signed trade agreements not only with almost all Latin American countries, but also with United States, European Union and Asia in recent years.

\footnotetext{
${ }^{1}$ IRS in trade models are usually modeled by fixed and constant marginal costs, implying declining average costs. A more precise link to productivity can be made by assessing that the fixed cost might represent an investment in technology that is conditioned by the anticipation of the demand size and profits (Rodrik (1988), Bas and Ledezma (2006))
} 
Graph 5.1.:

Evolution of Nominal Tariffs in Chile: 1979-2000

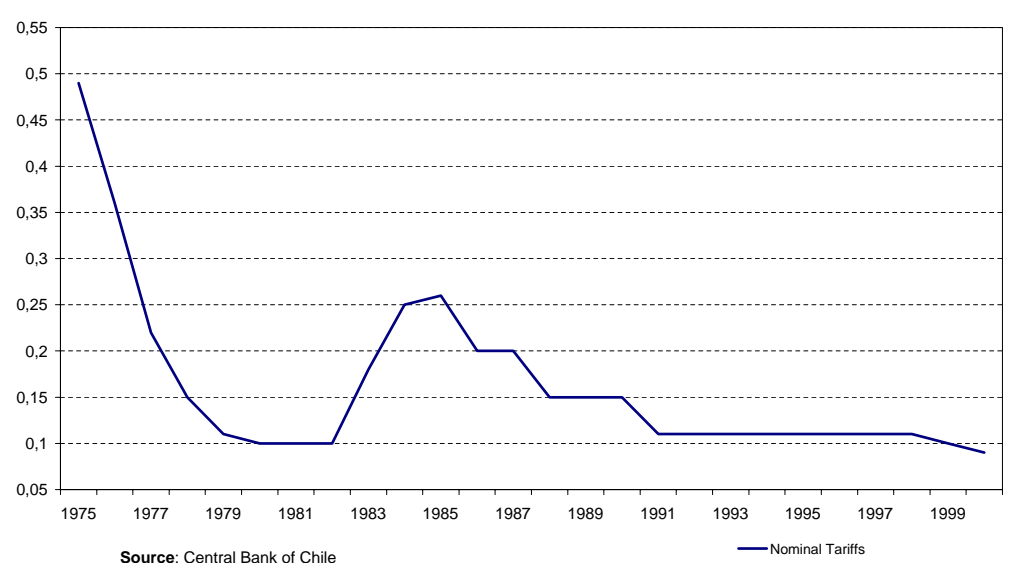

Graph 5.2

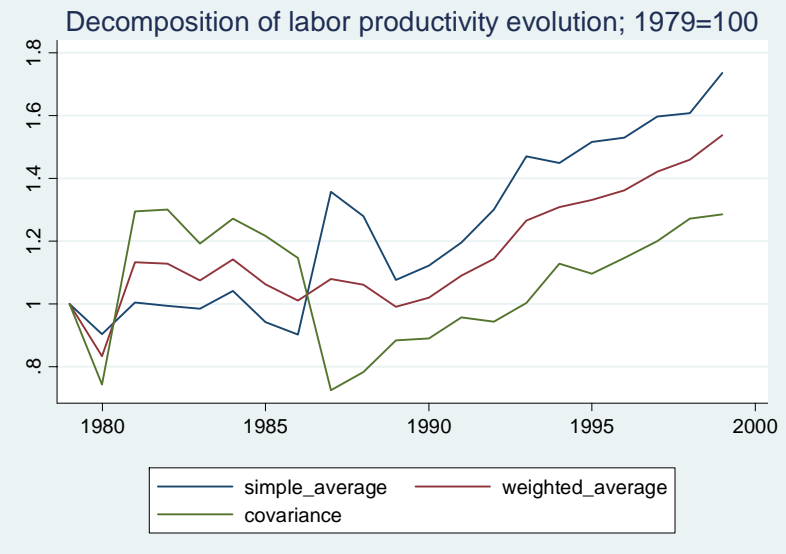

Graph 5.2 plots the average evolution of the weighted (by market share) and unweighted average labor productivity between 1979 and 2000. While the unweighted average labor productivity is directly related to within plant productivity, the weighted measure takes into account the gains due to the reallocation of market shares towards the most productive firms. As the graph shows, this evidence indicates that after 1987 within plant productivity gains 
become a key mechanism rather than the reallocation process. Consequently we focus on mechanisms that modify individual productivity after a change in the exposure to trade rather than to ex-ante self-selection mechanisms that, holding individual productivity constant, alter the composition of the average weighted productivity.

Several works have estimated the effects of trade reforms on firm's productivity using specific methodologies to estimate production functions, such as Olley and Pakes (1996) (OP) or Levinsohn and Petrin (2003) (LP) (See section 4.1.1). These methodologies allow estimating production functions in a framework of firm heterogeneity. We are particularly interested in two works that have also studied the Chilean experience. Based on the ENIA Survey, Pavcnik (2002) estimates the impact of trade on plant's productivity in Chile during the period 1979-1986. She applies OP strategy and controls explicitly for simultaneity and selection issues. Using year dummy variables as proxies of trade reform (treatement effect in a difference in difference framework), the conclusion of Pavcnik (2002) is that aggregate productivity improvements are explained by two factors induced by trade liberalization: (a) the growth of within plant productivity in importing-competing industries and (b) the exit of less productive firms and the corresponding reallocation of market share towards most productive ones. However, as Bergoeing, Hernando and Repetto (2006) note tariffs rose between 1983 and 1985 (see graph 5.1 in Appendix 1). Due to the debt and recession crisis in 1982, the government increased tariffs and nominal averages to $26 \%$ between 1983 and 1985 . Moreover these year dummies are also supposed to be a control of other macro economic shocks, namely the debt crises and other market reforms. Using year indicators in interactions with trade orientation sectors implies the implicit assumption that these macro economic shocks affect all sectors in a uniform way.

Chilean market reforms were recently revisited by Bergoeing, Hernando and Repetto (2006). They study the impact of trade and financial liberalization on productivity gains in Chile in a longer period of time (1980-2001) using the LP strategy. Their results show that aggregate productivity gains come from within plant improvements over time in traded industries relative to non traded ones (during the nineties) and from the entry of more productive firms than the exiting ones. They also find that the process of resources reallocation among incumbents play a minor role enhancing aggregate productivity. When explicitly regressing by effective tariffs productivity advantages of traded industries are not significant and import-competing sectors get (significantly) productivity gains from protection. 
Unfortunately for identification issues the drop of Chilean tariffs was quite radical but homogeneous across industries. This is probably the reason why Pavcnik (2002) is constrained to use year dummies and the reason why Bergoeing, Hernando and Repetto (2006) can not get enough variance for their estimates. Estimating the evolution of market access (border effects) between Chile and its trading partners also allows us to identify heterogeneity across industries and time. In that sens this paper yields new findings of trade policy implications. In order to facilitate the comparison of the results with previous works we also distinguish between export oriented, import competing and non traded sectors. We start reproducing Pavcnik's (2002) results for the full sample period. Then we run the regressions of productivity using the measures of border effects in interaction with traded sectors relative to non traded ones. First, we find a positive significant effect of a reduction of export barriers on productivity in both export oriented and import competing sectors. Second, we also find evidence of a positive impact of the reduction of import difficulties on productivity in export oriented industries. Finally, the regressions show that the decrease in import barriers might have a negative impact on productivity in import competing industries. This latter result implies that industries in import competing sectors may actually suffer from foreign competition probably by reducing their domestic market size and the possibility to exploit increasing returns.

The rest of the paper is organized as follows. In Section 2 the estimation strategy in three steps is presented. Section 3 discusses the main estimation results. Section 4 concludes.

\section{Estimation Strategy}

The estimation strategy consists of three steps. In the first step we estimate the production function using OLS, Fixed Effects and LP methodology to obtain the factor elasticity coefficients and to calculate total factor productivity (TFP) of Chilean manufacturing plants. In the second step, we construct the measure of trade liberalization estimating the border effects coefficients using a gravity model developed by Fontagne, Mayer and Zignago (2006). Finally, in the third step we estimate the impact of trade difficulties regressing productivity on border effects coefficients in interaction with sectors defined by trade orientation (export, import competing and non traded industries). 


\subsection{Step 1: Specification of production function esti- mations}

As usually plant's TFP is calculated as the residual between the observed value added and the estimates of factors contribution. In order to do so we must estimate the production function at two digit industry level. When estimating production functions using firm panel data eventual problems concerning simultaneity and selection should be considered. Simultaneity arises because inputs demand and productivity are positively correlated. Firm specific productivity is known by the firm but not by the econometrician and panel data information usually shows that productivity is heterogeneous among firms and it evolves over time. A high productivity shock implies greater demand and consequently firms must purchase more inputs. OLS will tend to provide upwardly biased estimates of labor coefficients. If capital is positively correlated with labor and labor's correlation with the productivity shock is higher than capital one, which is the realistic case, then the coefficient of capital may be underestimated.

Selection problems are likely to be present because unobserved productivity influences the exit decision and we only observe those firms that decide to stay. On the other hand, if capital is positively correlated with profits, firms with larger capital stock will anticipate higher profits and decide to stay in the market even for low realizations of productivity shocks. So at the end, there is a potential source of negative correlation in the sample between productivity shocks and capital stock. This negative correlation means a downward bias in capital elasticity estimates.

Olley and Pakes (1996) (OP) propose a methodology of three stages to control for unobserved productivity incorporating exit and investment rules derived from firm optimal behaviour. In the first stage they use the investment rule, a function of capital stock and unobserved productivity, to address simultaneity. OP invert this investment rule to express unobserved productivity as a function of investment and capital. This inverted function is used as a proxy for productivity in the estimation. In the second stage, based on the exit rule they estimate the probability of survival conditional on available information to the firm. Following an optimal behaviour their exit rule states that firms decide to exit the market if productivity realization shocks are lower than a specific productivity cut-off which in turn is determined by capital stock and productivity. The estimates of this survival probability are used to control for selection bias. To obtain the capital coefficient, we substitue the estimates of labor coefficient (stage 1), the productivity function 
(inverted investment decision) and the survival probability (stage 2) into the production function equation.

Besides some technical differences (such us the use of GMM criterion and bootstraps), Levinsohn and Petrin (2003) (LP) make use of this strategy and extend it showing that inputs (like electricity or materials) can be better proxies to control for unobserved productivity when one deals with simultaneity. Inputs adjust in a more flexible way, so they are more likely to have better responsive to productivity shocks. Moreover, inputs usually have more non-zero observations than investment, a property that has consequences on estimation efficiency. In the case of the ENIA this property is important. As LP show the risk of selection biases are significantly reduced by considering a non balanced panel.

There are some advantages of OP-LP strategy over alternative methods. Firstly, it performs better than fixed effects because it does not assume that the unobserved individual effect (productivity) is constant over time when controlling for simultaneity. Secondly, approaches based on instrumental variables can be limited by the instruments availability. Finally, it does not assume restrictions on the parameters. For instance, an alternative approach is the one developed by Katayama, Lu and Tybout (2005). They show how misleading can be the use of sale revenues to measure output in productivity accounting. Factor prices and mark-ups can produce important distortions if they are not homogeneous. However, the methodology proposed in their paper assumes constant returns to scales and neglect entry-exit process to facilitate likelihood estimates. Again both assumptions are not neutral in the case of the ENIA.

In order to maximize sample size with a reduced risk of selection we keep the LP strategy and use electricity as a proxy for unobserved productivity. In the first step, we will estimate the following specification of a Cobb Douglas production function:

(1) $y_{i t}=\beta_{0}+\beta_{1} x_{i t}+\beta_{2} k_{i t}+\varepsilon_{i t}$

Where all variables are expressed in natural logarithmics, " $y_{i t}$ " is the value added of plant "i", " $x$ " are variable inputs (skilled and unskilled labor) and " $k$ " is the stock of capital. Consequently, TFP in $\log \left(a_{i t}\right)$ is computed as the residual of this function, given by:

$$
\widehat{a}_{i t}=y_{i t}-\widehat{\beta}_{1} x_{i t}-\widehat{\beta}_{2} k_{i t}
$$




\subsection{Step 2: Specification of Border Effects estimation}

It is well known that the reduction of tariffs in Chile was homogeneous across industries. As a consequence we do not have variance in tariffs measures among industries. Even their rise in early eighties, during the deep Chilean debt crisis, was homogeneous. On the other hand, tariffs are not the only measure that matter in trade. One should consider bilateral agreements, asymmetries between export and import costs and industrial specific difficulties to trade, not only concerning direclty policies but also home biases, tastes and the like. Actually, by considering all these issues we obtain heterogeneity in both industrial and time dimensions.

Using a gravity equation framework, we measure the difficulties of bilateral trade explained by the fact of crossing the border between two countries. We apply to Chile and Chilean's trade partners the methodology developed by Fontagne, Mayer and Zignago $(2005)^{2}$. The gravity bilateral trade equation that we estimate is based on a comparison between international $\left(m_{i j s}\right)$ and intra-national trade flows $\left(m_{i i s}\right)$, the latter being a kind of ideal type of free trade.

$$
\frac{m_{i j s}}{m_{i i s}}=\left(\frac{a_{i j}}{a i i}\right)^{\sigma-1}\left(\frac{p_{j}}{p_{i}}\right)^{-\sigma}\left(\frac{\tau_{i j}}{\tau_{i i}}\right)^{1-\sigma}\left(\frac{v_{j s}}{v_{i s}}\right)
$$

$m_{i j s}$ : imports of industry "s" in country "i" from country "j"

$m_{i i s}$ : volume of trade within a country measured as the overall production minus total exports in industry "s" in country "i".

$a_{i j}$ : consumer preferences of country " $\mathrm{i}$ " with respect to varieties produced in $\mathrm{j}$.

$v_{j s}$ : the value of production in industry "s" in country "j"

$p_{j}$ : Index price in country " $\mathrm{j}$ "

Trade costs $\left(\tau_{i j}\right)$ are composed by distance $\left(d_{i j}^{\delta}\right)$ (related to transport costs), advalorem tariffs $\left(t_{i j}\right)$ and "tariff equivalent" of non tariff barriers $\left(N T B \_i j\right)$

$$
\tau_{i j} p_{j} \equiv d_{i j}^{\delta}\left(1+t_{i j}\right)\left(1+N T B_{i j}\right) p_{j} .
$$

The structure of protection varies across all partner pairs and depends on the direction of the flow for a given pair. To capture this protection

\footnotetext{
${ }^{2}$ Omitted here, they develop further steps to disentangle the origin of the border effect. We are interested in the residual measure involving all policy difficulties, tariff and non tariff barriers, agreements, political efforts and the like.
} 
framework, taking the example of the US as trade partner, the following dummy structure is defined:

$$
\left(1+t_{i j}\right)\left(1+N T B_{i j}\right) \equiv \exp \left[\eta U S A-C H L_{i j}+a C H L-U S A_{i j}\right]
$$

USA-CHL $L_{i j}$ : is a dummy variable set equal to 1 when $\mathrm{j}(\neq \mathrm{i})$ is Chile and i the USA (related to imports of USA from Chile).

$\mathrm{CHL}_{\mathrm{USA}}$ : is a dummy variable set equal to 1 when $\mathrm{j}(\neq \mathrm{i})$ is the US and i Chile (imports of Chile from USA).

Preferences $a_{i j}$ are composed by a random component $e_{i j}$ and the coeficient $\beta$ which represents a systematic preference for goods produced in the home country. This "home market bias" is reduced to $\left(\beta_{i}-\lambda\right)$ when the countries share the same language $\left(L_{i j}=1\right)$ :

$$
a_{i j} \equiv \exp \left[e_{i j}-\left(\beta_{i}-\lambda L_{i j}\right)\left(U S A-C H L_{i j}+C H L-U S A_{i j}\right)\right]
$$

Combining the previous equations, we obtain the estimable equation:

$$
\begin{aligned}
& (2) \ln \left(\frac{m_{i j s}}{m_{i i s}}\right)=\ln \left(\frac{v_{j s}}{v_{i s}}\right)-(\sigma-1) \delta \ln \left(\frac{d_{i j}}{d_{i i}}\right)+(\sigma-1) \lambda L_{i j}-\sigma \ln \left(\frac{p_{j}}{p_{i}}\right) \\
& -(\sigma-1)\left[\beta_{i}+\eta\right] U S A_{-} C H L_{i j}-(\sigma-1)\left[\beta_{i}+a\right] C H L_{-} U S A_{i j}+Z_{i j}+\epsilon_{i j}
\end{aligned}
$$

This equation can be estimated at country level (considering all industries) and also at industry level. From the latter estimation we obtain the global border effect measure for each industry as a weighted average of all trading partners. The border effect coefficient of each import (export) flow will be weighted by the share of the flow on total imports (exports). Since we drop the constant and incorporate dummy variables for each combination, the coefficients of the dummy variables can be interpreted as the border effect of each combination. For example, the exponential of the coefficient of $U S A-C H L_{i j}$ multiplied by $-1, \exp \left((\sigma-1)\left[\beta_{i}+\eta\right]\right)$ indicates the difficulty for Chilean's exporters in accessing to the US markets. The part of missing trade mainly caused by trade policy is captured in these coefficients.

In the estimation we consider not only the US but also other countries trading with Chile. To determine the main trading partners of Chile we use the aggregated trade flows data of ECLAC. Between 1990 and 1999 the main destination countries of Chile manufacturing exports are Latin America 
(AL), the United States (USA) and the European Union (UE). At the same time, most manufacturing imports from Chile come from these countries. In the Border Effects regressions we consider nine countries of European Union , which were members through out the whole period (1979-1999). ${ }^{3}$

Finally, there is a potential source of endogeneity since in step three we will use these border effect coefficients to estimate the impact of trade liberalization on plant's TFP in different sectors. Most productive sectors or those producing high quality goods will tend to increase their trade flows and to have a smaller border effect. To address this issue we use relative wages and productivity as control variables (Zij) in the estimation of border effects. In that sense the residual measure of missing trade that is captured by the border effect will be free of productivity concerns.

\footnotetext{
${ }^{3}$ Germany, France, Great Britain, Italy, Belgium, Luxembourg, Ireland, Netherlands and Denmark
} 


\subsection{Step 3: Specification of the estimation of the im- pact of trade liberalization on TFP}

In this final step we use the (weighted average) border effect estimated for each industry to measure the impact of trade liberalization on productivity across export and import competing sectors relative to non traded industries. We estimate the following reduced equation similar to the difference in difference framework implemented by Pavcnik (2002):

(3) $\widehat{a}_{i t}=\alpha_{0}+\beta(B E)+\gamma($ Sector $)+\delta(B E *$ Sector $)+\lambda Z_{i t}+\epsilon_{i t}$

$a_{i t}: \log$ of plant's TFP estimated by LP strategy or by Fixed Effects.

$B E$ : vector of import border effect $\left(B E_{-} M\right)$ and export border effect estimates $\left(B E_{-} X\right)$ at two digit industry level

Sector: vector of trade orientation dummies ${ }^{4}$ : export oriented (Export) and import competing (Import) industries.

$Z i j$ : vector of plant characteristics: industry affiliation (ISIC 3 Ind), competition (ind_comp) and indicators of entry and exit (Entry_indicator; Exit_indicator))

The excluded categories are non traded sector, the year 1979 and the sector $385^{5}$. We are principally interested in the estimates of the vector coefficient $\delta$. It is usually expected a negative and significant coefficient meaning that a reduction of trade barriers has a higher positive effect on productivity in traded industries (export oriented and import competing) than in non traded ones. The vector coefficient $\gamma$ informs about the relative productivity advantage of traded industries in Chilean manufacture.

\footnotetext{
${ }^{4}$ We classified sectors by trade orientation using 4 digit industry classification. Plants belonging to 4 digit industry which have more than $15 \%$ of exports over total production are classified as exported oriented plants; while plants belonging to 4 digit industry which have more than $15 \%$ of import penetration indicator are classified as import competing plants. The rest are considered as non traded plants. See Pavcnik (2002) for further details concerning this classification.

${ }^{5}$ Manufacture of professional and scientific, measuring and controlling equipment not elsewhere classified, and of photographic and optical goods
} 


\subsection{Data}

In the first step we use manufacturing plant level data from the ENIA Survey provided by the Chilean institute of statistics INE (Instituto Nacional de Estadisticas). This survey is a manufacturing census of Chilean plants with more than 10 employees. Our data covers the period 1979-2000 and contains information concerning mainly added value, materials, labor, investment and exports (only available from 1990). The ENIA survey has been used in previous studies such as Pavcnik (2002), Liu and Tybout (1996), Levinsohn and Petrin (2003) and Bergoeing, Hernando and Repetto (2006) for different sample periods. We used several specific deflators (at three digit Isic-Rev2 and year base 1992) for added value, exports, materials and investment. Capital series were constructed using the methodology developed by Bergoeing, Hernando and Repetto (2006). Table 5.2 (Appendix 1) shows general descriptive statistics of the sample.

In the second step we use data from "Trade and Production Database" constructed by CEPII using mainly data of the World Bank. In this compilation, production variables are completed with the UNIDO and the OECD STAN databases, and trade variables with the international trade database (BACI) available from CEPII. This database is provided at the ISIC rev2 3-digit industry level over the period 1976-1999 for 67 developing and developed countries. For distance variables, contiguity and common language, we also used the CEPII database of internal and external distances. Distances variables between two countries are measured based on bilateral distance between cities weighted by the share of the city in the overall country's population. Finally, price indexes steam from Penn World Table as price level of GDP expressed relative to United States. Following Fontagne, Mayer and Zignago (2005), we use aggregate price indexes instead of industrial wages or (the unavailable) prices at industry level to reduce potential endogeneity problems. $^{6}$

\footnotetext{
${ }^{6}$ There is an endogeneity issue that arise using price indexes in the estimation of border effects. Trade flows are determined by relative prices which are also a function of border barriers and consequently, they also depend on trade flows. Fontagne, Mayer and Zignago (2006) estimate border effects at industry level and they address this issue using aggregate price indexes, which are less likely to be correlated to industry level changes in expected profits than industry prices
} 


\section{Results}

\subsection{Results step 1: T.F.P. estimations}

In this step we estimate the equation (1) a Cobb Douglas production function at 2 ISIC industry level using OLS, Fixed Effects and LP strategy. Table 3.1. shows the results. As expected, LP estimates of unskilled labor elasticities are generally the lowest and those of capital elasticities the highest, meaning that the biases induced by the higher responsiveness of the labor input respect to capital are addressed. Considering LP estimates, in five industries ${ }^{7}$, among them the main exporters, we can not reject at $5 \%$ the null hypothesis of constant returns to scale in the Wald test. On the other hand, industries presenting increasing returns to scale are mainly importers. For these industries the size of the market may affect positively their productivity.

After estimating production function coefficients we calculate TFP as a residual measure. In Graph 3.1 the evolution of different measures of plant's productivity is presented: fixed effects (TFP_fe), LP (TFP $l p)$, OLS (TFP_ols) and the sample mean of valued added over labor (lnproductivity)

${ }^{7}$ Food (31), wood (33), non metallic minerals (36) and basic metals (37) and other (39) 
Table 3.1.: Estimates of Production Function

\begin{tabular}{|c|c|c|c|c|c|c|c|}
\hline \multirow[t]{3}{*}{$\begin{array}{l}\text { Industry } \\
\end{array}$} & \multirow[t]{3}{*}{ Factors } & \multicolumn{2}{|c|}{ OLS } & \multicolumn{2}{|c|}{$\begin{array}{l}\text { FIXED EFFECTS } \\
\end{array}$} & \multicolumn{2}{|c|}{ L.P. Semiparametric } \\
\hline & & \multicolumn{2}{|c|}{$\begin{array}{ll} & {[1]}\end{array}$} & \multicolumn{2}{|c|}{ [2] } & \multicolumn{2}{|c|}{ [3] } \\
\hline & & Coef & S.E. & Coef & S.E. & Coef & S.E. \\
\hline \multirow{4}{*}{$\begin{array}{l}\text { Food and } \\
\text { Beverage }\end{array}$} & $U$ & 0,815 & 0,010 & 0,627 & 0,012 & 0,570 & 0,024 \\
\hline & $\mathrm{S}$ & 0,359 & 0,009 & 0,159 & 0,008 & 0,212 & 0,015 \\
\hline & $\mathrm{K}$ & 0,250 & 0,005 & 0,083 & 0,007 & 0,208 & 0,046 \\
\hline & $\mathrm{N}$ & 18559 & & & & & \\
\hline \multirow[t]{4}{*}{ Textil } & $U$ & 0,833 & 0,011 & 0,777 & 0,014 & 0,710 & 0,024 \\
\hline & $\mathrm{S}$ & 0,202 & 0,010 & 0,165 & 0,009 & 0,174 & 0,018 \\
\hline & $\mathrm{K}$ & 0,206 & 0,005 & 0,102 & 0,008 & 0,249 & 0,034 \\
\hline & $\mathrm{N}$ & 11063 & & & & & \\
\hline \multirow[t]{4}{*}{ Wood } & $U$ & 0,865 & 0,017 & 0,849 & 0,021 & 0,681 & 0,034 \\
\hline & $\mathrm{S}$ & 0,208 & 0,015 & 0,095 & 0,014 & 0,131 & 0,021 \\
\hline & $\mathrm{K}$ & 0,209 & 0,009 & 0,104 & 0,013 & 0,275 & 0,040 \\
\hline & $\mathrm{N}$ & 5711 & & & & & \\
\hline \multirow[t]{4}{*}{ Paper } & $U$ & 0,763 & 0,018 & 0,539 & 0,024 & 0,692 & 0,044 \\
\hline & $\mathrm{S}$ & 0,252 & 0,014 & 0,175 & 0,015 & 0,207 & 0,025 \\
\hline & $\mathrm{K}$ & 0,229 & 0,010 & 0,182 & 0,014 & 0,299 & 0,055 \\
\hline & $\mathrm{N}$ & 3175 & & & & & \\
\hline \multirow[t]{4}{*}{ Chemicals } & $\mathrm{U}$ & 0,604 & 0,016 & 0,639 & 0,017 & 0,528 & 0,045 \\
\hline & $\mathrm{S}$ & 0,337 & 0,015 & 0,168 & 0,013 & 0,266 & 0,028 \\
\hline & $\mathrm{K}$ & 0,294 & 0,008 & 0,149 & 0,011 & 0,354 & 0,057 \\
\hline & $\mathrm{N}$ & 6588 & & & & & \\
\hline \multirow{4}{*}{$\begin{array}{c}\text { Non metalic } \\
\text { products }\end{array}$} & $U$ & 0,780 & 0,028 & 0,797 & 0,031 & 0,577 & 0,074 \\
\hline & $\mathrm{S}$ & 0,241 & 0,026 & 0,130 & 0,025 & 0,103 & 0,049 \\
\hline & $\mathrm{K}$ & 0,244 & 0,013 & 0,136 & 0,018 & 0,281 & 0,074 \\
\hline & $N$ & 2153 & & & & & \\
\hline \multirow[t]{4}{*}{ Basic Metals } & $U$ & 0,280 & 0,070 & 0,346 & 0,061 & 0,217 & 0,104 \\
\hline & $\mathrm{S}$ & 0,485 & 0,063 & 0,161 & 0,045 & 0,263 & 0,094 \\
\hline & $\mathrm{K}$ & 0,412 & 0,042 & 0,059 & 0,049 & 0,290 & 0,189 \\
\hline & $\mathrm{N}$ & 640 & & & & & \\
\hline \multirow[t]{4}{*}{ Machinery } & $U$ & 0,897 & 0,012 & 0,766 & 0,015 & 0,767 & 0,033 \\
\hline & $\mathrm{S}$ & 0,242 & 0,011 & 0,204 & 0,011 & 0,178 & 0,022 \\
\hline & $\mathrm{K}$ & 0,164 & 0,006 & 0,111 & 0,010 & 0,236 & 0,058 \\
\hline & $\mathrm{N}$ & 8524 & & & & & \\
\hline \multirow[t]{4}{*}{ Other } & $U$ & 0,880 & 0,054 & 0,669 & 0,063 & 0,671 & 0,114 \\
\hline & $\mathrm{S}$ & 0,214 & 0,042 & 0,214 & 0,046 & 0,160 & 0,081 \\
\hline & $\mathrm{K}$ & 0,093 & 0,022 & 0,180 & 0,032 & 0,277 & 0,082 \\
\hline & $\mathrm{N}$ & 647 & & & & & \\
\hline
\end{tabular}

Note: U: unskilled labor, S: skilled labor, K: Capital and N: Observations 


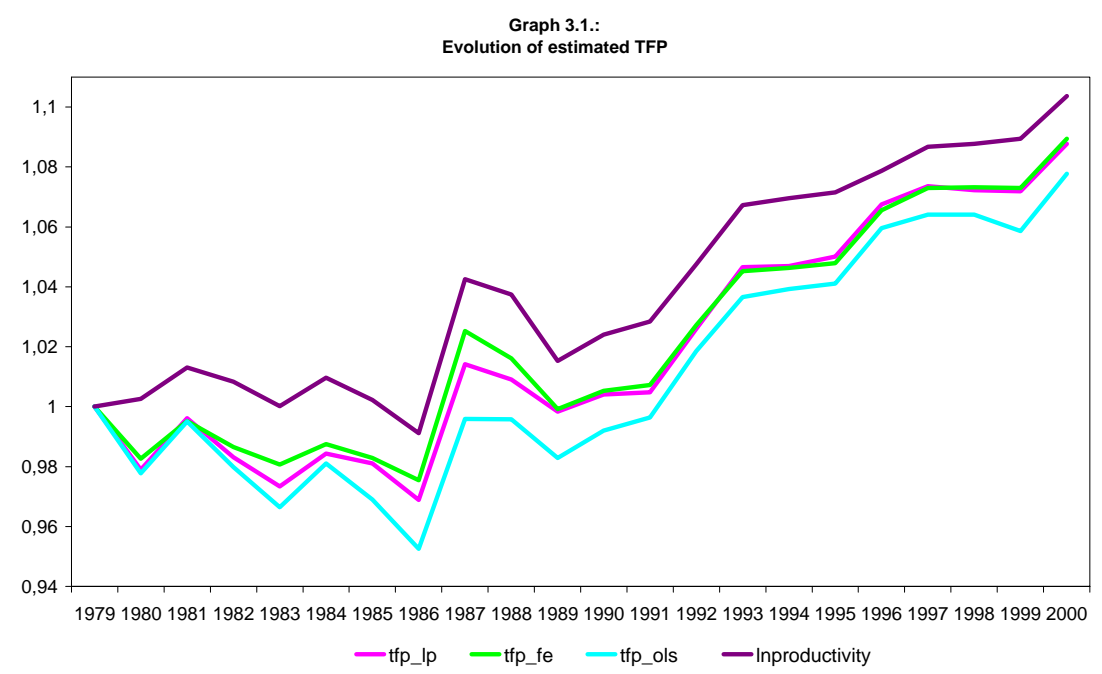

As a first robustness check of our performance measures, the graph shows that labor productivity and all TFP measures depict similar evolutions. Although the elasticities estimated by fixed effects and LP show some differences, the TFP path illustrated by both measures is very similar. Even if fixed effects TFP may overestimate capital coefficient and underestimate labor coefficient, after computing all factors contribution the evolution of the residual is not drastically affected.

Graph 3.1.2. shows the evolution of TFP (LP) by sector classified by trade orientation. Plants in export oriented sectors are in average more productive than those in import competing sectors. The productivity of non traded plants slows down during the eighties and it slightly recovers during the nineties but it is always behind the TFP of traded sectors. 


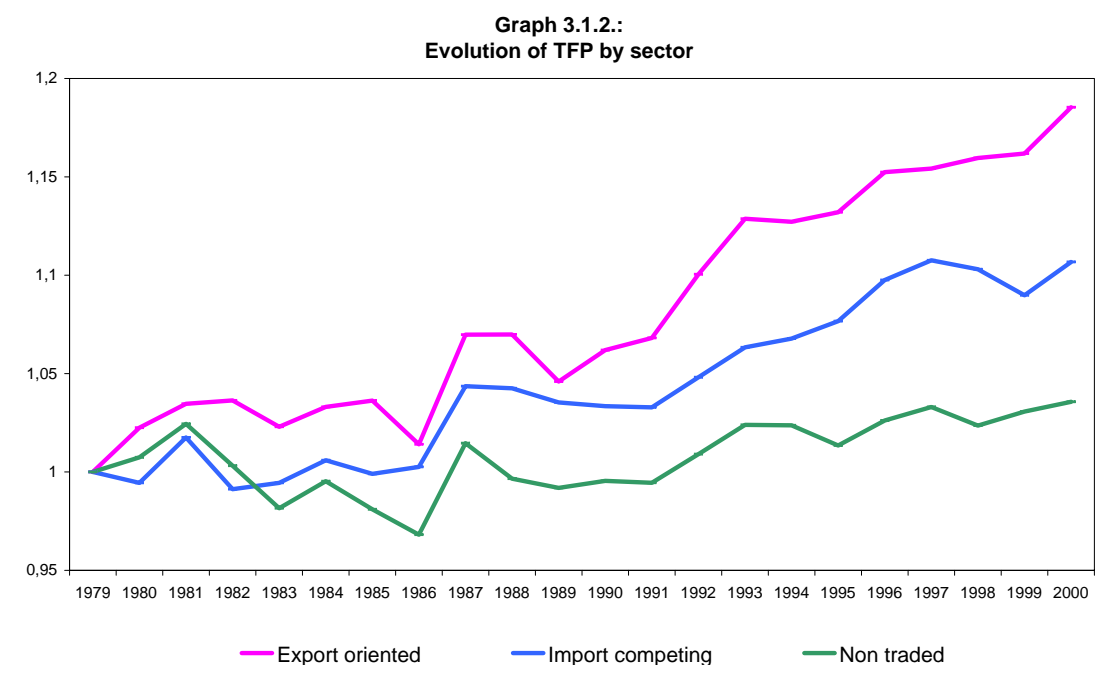

\subsection{Results step 2: Estimations of Border Effects}

In the second step we construct our measure of market access by estimating equation 2 to obtain border effects for five periods at two digit industry level. Graphs 3.2.1 and 3.2.2 show the evolution of the weighted average of border effects between Chile and the United States, Latin American countries and the European Union (weighted by the share of trade flows of each trade partner). All coefficients of border effects are significant at least at $10 \%$. Graph 3.2.1 shows the evolution of export border effects measuring the difficulties for Chilean's exporters to access foreign market. Export barriers were almost constant during the first half of eighties and even in some industries like woods they increased during this period. Reflecting asymmetries between import and export policies, export difficulties have considerably diminished in all industries during nineties (except for food industry) even if tariffs were already very low.

Graph 3.2.2 shows the evolution of the weighted average of import border effect measuring barriers faced by UE, LA and USA to access Chilean markets. In this case, in many industries the market access difficulties increased during the first half of eighties, which seems very consistent with the raise in import tariffs during this period. From 1987 to the end of nineties import 
border effects have been drastically reduced in almost all industries with the exception of basic metals, a traditional exporter industry.

Graph 3.2.1:

Estimation of Market access of Chilean's exporters

(weighted average of its main trading partners: UE, LA and USA)

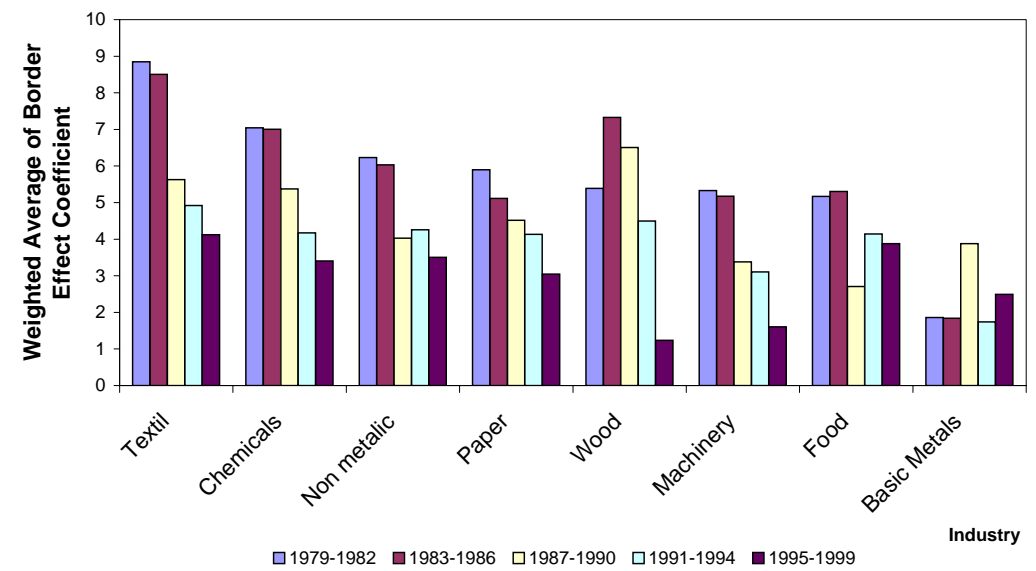

Graph 3.2.2:

Estimation of the weighted market acces of UE, LA and USA to Chile

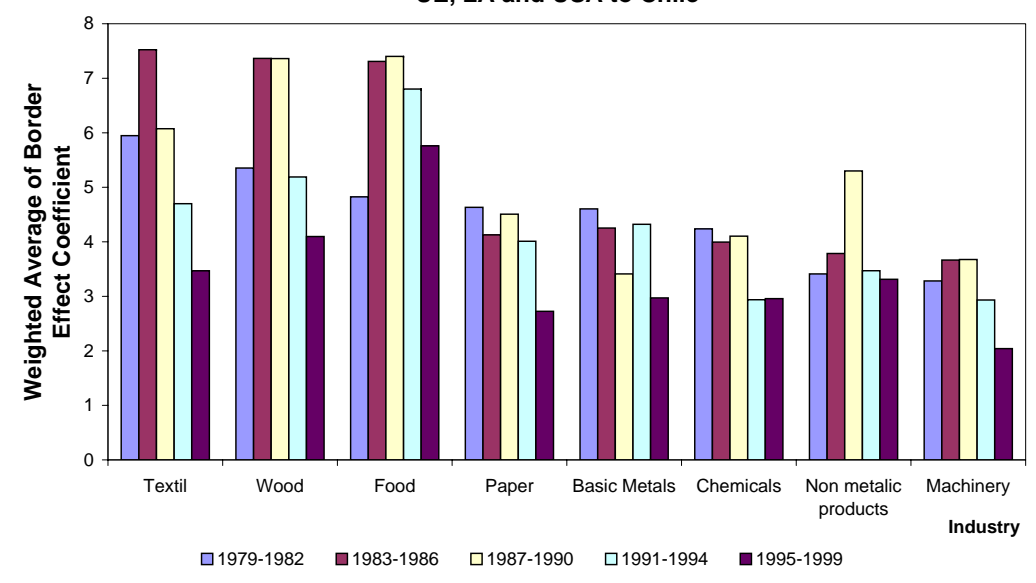




\subsection{Results step 3: The impact of Trade Liberalization on TFP}

The final step consists in identifying the influence of specific trade reforms on the evolution of plant's productivity. Equation (3) disentangles the variation in productivity due to changes in trade policy depending on trade orientation. We are interested in the coefficient vector $\delta$, concerning the interactions between the indicator of a plant's trade orientation and the measure of trade policy. These coefficients show the productivity differential for plants belonging to traded sectors relative to those belonging to non traded sectors, which is explained by the effect of trade policy.

In order to give baseline estimation, we first run the regressions in fixed effects using year dummy indicators as a measure of trade liberalization and we obtain similar results to Pavcnik (2002). Once controlling for exit and plant's specific characteristics, trade liberalization (if captured by year dummies) has a positive impact on productivity of traded sectors (export oriented and import competing) relative to non traded ones (see Appendix 2).

Now we use the weighted measures of border effects for each industry estimated in step 2 to analyse the impact of the outcome of export and import trade policies on plant's TFP. We check robustness of our results using as dependant variable TFP measured by fixed effects (Table 2) and LP (table 3) estimations. Once we use year and industry indicators to control for industry specific effects and macro economic shocks, the coefficients of the rest of variables will only capture the effects of within industry productivity variation. We also use Huber-White estimator of variance to correct standard errors.

In the first column (table 2 and table 3 ) we run the regression without controling for exit, entry indicators and domestic competition. Giving our framework we interpret the coefficients of interactions relative to non traded sector, the omitted category. The export border effect in the two interactions terms (with the export oriented and the import competing dummies) presents a negative and significant coefficient. This suggests a positive impact of a reduction of export barriers on plant's productivity in both export oriented and import competing sectors. The regression aims at capturing within plant productivity improvements as a consequence of trade policies rather than aggregate productivity improvements coming from reallocation and firm renewal. In that sense what we observe may be related to externalities captured after exporting such as learning by exporting and knowledge spillovers coming from international markets (Aw, Chung, Roberts, 1999). 
Regarding the called "import competing sectors", this positive effect of the reduction of export barriers can be driven by exporters inside these sectors. It is well documented in firm heterogeneity literature that even in narrow defined industries exporters and importers compete with some degree of differentiation. The reduction of export costs will allow new firms start exporting. Bergoeing, Micco and Repetto (2005) show that there were many plants that started exporting during the nineties in Chilean industries having a small aggregate export share.

Concerning the impact of import barriers, the results depend on the sector. We find evidence of a negative effect of a reduction of import barriers on productivity of plants belonging to import competing sectors (the interaction between import border effect and import competing sector). Therefore, increasing foreign competition will dampen the productivity of plants in these sectors. As suggested by Bergoeing, Hernando and Repetto (2006) this fact may be related to increasing returns. We observed in the estimates of production functions that import competing industries present in general increasing returns to scale. Foreign competition reduces the market shares of domestic firms shrinking the opportunities to exploit economies of scales.

On the other hand, the reduction of the difficulties of foreign exporters to access the Chilean market (the reduction of import barriers) has a positive impact on productivity in export oriented sectors (the interaction between import border effect and export oriented sector). A better access to new technologies and to high quality inputs may explain this within plant productivity improvement. In the case of import competing sectors, the negative effect of market size may be negative enough to counteract this positive outcome.

Once we control for exit (column 2), entry (column 3) and domestic competition using a Herfindahl indicator of market concentration (column 4) the results remain almost unchanged. As expected, the exit indicator has a negative coefficient meaning that exiting firms are less productive than those that decide to stay in the market. Exiting plants are on average $17 \%$ less productive than surviving plants. The coefficient of the entry indicator is also negative indicating that new firms are roughly $5 \%$ less productive than incumbents. The coefficient of domestic competition is negative (though less significant), implying that a reduction of market concentration will enhance productivity. Finally note that the coefficients of both border effects (without interaction) are positive and significant, meaning that the improvement of market access in both sides may have negative effects on productivity in non traded sectors (put zeros in import competing and export oriented dummies). This may be explained by general equilibrium effects that should be 
studied in more detail ${ }^{8}$. By the moment we will concentrate on relative effects.

We also check robustness of these results using a moving average of border effects to take into account the possible "lagged" impact of trade reform on plant's productivity. It might be the case that plants do not react instantaneously to changes in trade policies. To control for this issue, we construct a moving average of four years of each border effect at industry level. For example, the border effect of the year 1982 is an average of border effects from 1979 to 1982. Therefore, in the regression of TFP on border effects we lose the three first years $(1979,1980$ and 1981). The last column reports the results of this estimation. In the case of the TFP measured by fixed effects (table 2) the coefficients of all interactions between border effects and sector trade orientation remain significant and with the same sign but they have a lower value. Nevertheless, when we used the TFP estimated by LP strategy (table3), the coefficients of the interaction between import barriers and import competing sector is non significant. In this last specification, all other coefficients remain significant and with the same sign.

To sump up, we find robust evidence that traded sectors increase their productivity, relative to non traded sectors, as a consequence of export oriented policies. In the case of import oriented policies the effects on productivity depends on sectors. While export oriented sectors improve their productivity, probably thanks to the increase in the foreign demand and the easier access to imported inputs and technology, domestic plants competing with imports may suffer from this foreign competition.

\footnotetext{
${ }^{8}$ One possible mechanism may be the increase in the cost of the (mobile) labor factor as a consequence of the increasing foreign demand. This may induce imperfect substitution in consumption towards foreign exporter. This will reduce the size of local firms and avoid the exploitation of economies of scales.
} 
Table 1: The impact of TL on productivity: TFP_FE

\begin{tabular}{|c|c|c|c|c|c|}
\hline Model & {$[\mathbf{F E ~ ( 1 ) ] ~}$} & [FE (2)] & {$[\mathrm{FE} \mathrm{(3)]}$} & {$[\mathrm{FE} \mathrm{(4)]}$} & {$[\mathrm{FE} \mathrm{(5)}$} \\
\hline Export & $\begin{array}{c}1.295^{* * *} \\
(0.351)\end{array}$ & $\begin{array}{c}1.310^{* * *} \\
(0.347)\end{array}$ & $\begin{array}{c}1.307^{* * *} \\
(0.345)\end{array}$ & $\begin{array}{c}1.160^{* * *} \\
(0.348)\end{array}$ & $\begin{array}{c}0.878^{* *} \\
(0.435)\end{array}$ \\
\hline Import & $\begin{array}{c}0.827^{* * *} \\
(0.319)\end{array}$ & $\begin{array}{c}0.842^{* * *} \\
(0.314)\end{array}$ & $\begin{array}{c}0.833^{* * *} \\
(0.312)\end{array}$ & $\begin{array}{c}0.722^{* *} \\
(0.314)\end{array}$ & $\begin{array}{c}-2.154^{* * *} \\
(0.462)\end{array}$ \\
\hline Export*BE_X & $\begin{array}{c}-0.023^{* * *} \\
(0.006)\end{array}$ & $\begin{array}{c}-0.022^{* * *} \\
(0.006)\end{array}$ & $\begin{array}{c}-0.021^{* * *} \\
(0.006)\end{array}$ & $\begin{array}{c}-0.021^{* * *} \\
(0.006)\end{array}$ & $\begin{array}{c}-0.012^{*} \\
(0.007)\end{array}$ \\
\hline Import*BE_X & $\begin{array}{c}-0.098^{* * *} \\
(0.007)\end{array}$ & $\begin{array}{c}-0.097^{* * *} \\
(0.007)\end{array}$ & $\begin{array}{c}-0.096^{* * *} \\
(0.007)\end{array}$ & $\begin{array}{c}-0.096^{* * *} \\
(0.007)\end{array}$ & $\begin{array}{c}-0.046^{* * *} \\
(0.007)\end{array}$ \\
\hline Export*BE_M & $\begin{array}{c}-0.037^{* * *} \\
(0.009)\end{array}$ & $\begin{array}{c}-0.036^{* * *} \\
(0.009)\end{array}$ & $\begin{array}{c}-0.035^{* * *} \\
(0.009)\end{array}$ & $\begin{array}{c}-0.032^{* * *} \\
(0.009)\end{array}$ & $\begin{array}{c}-0.058^{* * *} \\
(0.010)\end{array}$ \\
\hline Import*BE_M & $\begin{array}{c}0.066^{* * *} \\
(0.010)\end{array}$ & $\begin{array}{c}0.064^{* * *} \\
(0.010)\end{array}$ & $\begin{array}{c}0.064^{* * *} \\
(0.010)\end{array}$ & $\begin{array}{c}0.067^{* * *} \\
(0.010)\end{array}$ & $\begin{array}{c}0.022^{* *} \\
(0.011)\end{array}$ \\
\hline BE_X & $\begin{array}{c}0.072^{* * *} \\
(0.006)\end{array}$ & $\begin{array}{c}0.072^{* * *} \\
(0.006)\end{array}$ & $\begin{array}{c}0.072^{* * *} \\
(0.006)\end{array}$ & $\begin{array}{c}0.073^{* * *} \\
(0.006)\end{array}$ & $\begin{array}{c}0.076^{* * *} \\
(0.007)\end{array}$ \\
\hline BE_M & $\begin{array}{c}0.042^{* * *} \\
(0.009)\end{array}$ & $\begin{array}{c}0.043^{* * *} \\
(0.009)\end{array}$ & $\begin{array}{c}0.043^{* * *} \\
(0.009)\end{array}$ & $\begin{array}{c}0.040 * * * \\
(0.009)\end{array}$ & $\begin{array}{c}0.038^{* * *} \\
(0.010)\end{array}$ \\
\hline Exit_ind & NO & $\begin{array}{c}-0.165^{* * *} \\
(0.012)\end{array}$ & $\begin{array}{c}-0.170 * * * \\
(0.012)\end{array}$ & $\begin{array}{c}-0.169^{* * *} \\
(0.012)\end{array}$ & $\begin{array}{c}-0.149^{* * *} \\
(0.013)\end{array}$ \\
\hline Entry ind & $\mathrm{NO}$ & NO & $\begin{array}{c}-0.055^{* * *} \\
(0.014)\end{array}$ & $\begin{array}{c}-0.055^{* * *} \\
(0.014)\end{array}$ & $\begin{array}{c}-0.067^{* * *} \\
(0.015)\end{array}$ \\
\hline ind_comp & $\mathrm{NO}$ & NO & NO & $\begin{array}{c}-0.247^{* * *} \\
(0.090)\end{array}$ & $\begin{array}{c}-0.187^{*} \\
(0.100)\end{array}$ \\
\hline ISIC 3 Ind & YES & YES & YES & YES & YES \\
\hline YEAR Ind & YES & YES & YES & YES & YES \\
\hline Obs & 56372 & 56372 & 56372 & 56372 & 46894 \\
\hline R-sq & 0.213 & 0.221 & 0.222 & 0.223 & 0.253 \\
\hline
\end{tabular}

Note: Huber White Standard errors in parentheses

${ }^{*} p<0.10,{ }^{* *} p<0.05,{ }^{* * *} p<0.01$ 
Table 2: The impact of TL on productivity: TFP_LP

\begin{tabular}{|c|c|c|c|c|c|}
\hline Model & {$[\mathrm{FE} \mathrm{(1)]}$} & {$[\mathrm{FE} \mathrm{(2)]}$} & {$[\mathrm{FE} \mathrm{(3)]}$} & {$[\mathrm{FE} \mathrm{(4)]}$} & {$[\mathrm{FE} \mathrm{(5)]}$} \\
\hline Export & $\begin{array}{c}2.168^{* * *} \\
(0.366)\end{array}$ & $\begin{array}{c}2.182^{* * *} \\
(0.363)\end{array}$ & $\begin{array}{c}2.179^{* * *} \\
(0.361)\end{array}$ & $\begin{array}{c}2.056^{* * *} \\
(0.366)\end{array}$ & $\begin{array}{l}-0.012 \\
(0.415)\end{array}$ \\
\hline Import & $\begin{array}{c}1.524^{* * *} \\
(0.337)\end{array}$ & $\begin{array}{c}1.538^{* * *} \\
(0.334)\end{array}$ & $\begin{array}{c}1.530^{* * *} \\
(0.331)\end{array}$ & $\begin{array}{c}1.437^{* * *} \\
(0.334)\end{array}$ & $\begin{array}{c}-1.789^{* * *} \\
(0.441)\end{array}$ \\
\hline Export*BE_X & $\begin{array}{c}-0.030^{* * * *} \\
(0.007)\end{array}$ & $\begin{array}{c}-0.029 * * * \\
(0.007)\end{array}$ & $\begin{array}{c}-0.028^{* * *} \\
(0.007)\end{array}$ & $\begin{array}{c}-0.028^{* * *} * \\
(0.007)\end{array}$ & $\begin{array}{c}-0.016^{* *} \\
(0.007)\end{array}$ \\
\hline Import*BE_X & $\begin{array}{c}-0.103^{* * *} \\
(0.007)\end{array}$ & $\begin{array}{c}-0.102^{* * *} \\
(0.007)\end{array}$ & $\begin{array}{c}-0.102^{* * *} \\
(0.007)\end{array}$ & $\begin{array}{c}-0.103^{* * *} \\
(0.007)\end{array}$ & $\begin{array}{c}-0.046^{* * *} \\
(0.008)\end{array}$ \\
\hline Export*BE_M & $\begin{array}{c}-0.037^{* * *} \\
(0.009)\end{array}$ & $\begin{array}{c}-0.036^{* * *} \\
(0.009)\end{array}$ & $\begin{array}{c}-0.036^{* * *} \\
(0.009)\end{array}$ & $\begin{array}{c}-0.033^{* * *} \\
(0.009)\end{array}$ & $\begin{array}{c}-0.067^{* * *} \\
(0.010)\end{array}$ \\
\hline Import*BE_M & $\begin{array}{c}0.063^{* * *} \\
(0.011)\end{array}$ & $\begin{array}{c}0.061^{* * *} * \\
(0.011)\end{array}$ & $\begin{array}{c}0.061^{* * *} \\
(0.011)\end{array}$ & $\begin{array}{c}0.063^{* * *} \\
(0.011)\end{array}$ & $\begin{array}{c}0.010 \\
(0.012)\end{array}$ \\
\hline BE_X & $\begin{array}{c}0.085^{* * *} \\
(0.007)\end{array}$ & $\begin{array}{c}0.084^{* * *} \\
(0.006)\end{array}$ & $\begin{array}{c}0.084^{* * *} \\
(0.006)\end{array}$ & $\begin{array}{c}0.085^{* * *} \\
(0.006)\end{array}$ & $\begin{array}{c}0.085^{* * *} \\
(0.007)\end{array}$ \\
\hline BE_M & $\begin{array}{c}0.042^{* * *} \\
(0.009)\end{array}$ & $\begin{array}{c}0.042^{* * *} \\
(0.009)\end{array}$ & $\begin{array}{c}0.042^{* * *} \\
(0.009)\end{array}$ & $\begin{array}{c}0.039^{* * *} \\
(0.009)\end{array}$ & $\begin{array}{c}0.045^{* * *} \\
(0.010)\end{array}$ \\
\hline Exit_ind & NO & $\begin{array}{c}-0.156^{* * *} \\
(0.012)\end{array}$ & $\begin{array}{c}-0.161^{* * *} \\
(0.012)\end{array}$ & $\begin{array}{c}-0.160^{* * *} \\
(0.012)\end{array}$ & $\begin{array}{c}-0.139^{* * *} \\
(0.013)\end{array}$ \\
\hline Entry ind & NO & NO & $\begin{array}{c}-0.050^{* * *} \\
(0.015)\end{array}$ & $\begin{array}{c}-0.050^{* * *} \\
(0.015)\end{array}$ & $\begin{array}{c}-0.064^{* * *} \\
(0.016)\end{array}$ \\
\hline ind_comp & NO & $\mathrm{NO}$ & NO & $\begin{array}{c}-0.239^{* *} \\
(0.094)\end{array}$ & $\begin{array}{l}-0.097 \\
(0.103)\end{array}$ \\
\hline ISIC 3 Ind & YES & YES & YES & YES & YES \\
\hline YEAR Ind & YES & YES & YES & YES & YES \\
\hline Number of Obs & 56372 & 56372 & 56372 & 56372 & 46894 \\
\hline R-sq & 0.243 & 0.243 & 0.250 & 0.250 & 0.253 \\
\hline
\end{tabular}

Note: Huber White Standard errors in parentheses

${ }^{*} p<0.10,{ }^{* *} p<0.05,{ }^{* * *} p<0.01$ 
As we mentioned, there is a potential endogeneity problem if we want to measure the impact of border effects on plant's productivity because border effects may depend on productivity. We already addressed this issue in the previous section when we estimated the border effects controlling by relative wages and productivity measures. Therefore, we expect that our estimates of border effects are free of the impact of industry productivity. Furthermore, we use border effects estimates at 2 digit industry level, while the dummy of industry trade orientation is defined at 3 digits. As an additional check we run quantile regressions (Koenker and Hallock, 2001). The idea is to estimate models for conditional quantile functions, that is, quantiles of the conditional distribution of TFP expressed as functions of the observed covariates. This allows asking whether the conditional fit of the mean is also representative for the median or other conditional quantiles. In that sense, if the weight of the border effect in the regression is driven by the most productive firms, this disparity should be reflected at different quantiles. Table 4 compares the coefficients in the estimation at the 25, 50 and 75 quantiles with the fixed effect estimation (around the mean) and shows that the magnitude, the significance and the sign of coefficients among the different fits do not change our conclusions.

Table 3: Quantile Regression

\begin{tabular}{lcccc}
\hline Model & {$[\mathbf{q 2 5}]$} & {$[\mathbf{q 5 0}]$} & {$[\mathbf{q 7 5}]$} & {$[$ Mean $]$} \\
\hline Export*BE_X & $-0.027^{* * *}$ & $-0.031^{* * *}$ & $-0.025^{* * *}$ & $-0.028^{* * *}$ \\
& $(0.008)$ & $(0.006)$ & $(0.007)$ & $(0.007)$ \\
Import*BE_X & $-0.089^{* * *}$ & $-0.095^{* * *}$ & $-0.097^{* * *}$ & $-0.103^{* * *}$ \\
& $(0.008)$ & $(0.006)$ & $(0.008)$ & $(0.007)$ \\
Export*BE_M & $-0.043^{* * *}$ & $-0.041^{* * *}$ & $-0.030^{* * *}$ & $-0.033^{* * *}$ \\
& $(0.011)$ & $(0.009)$ & $(0.010)$ & $(0.009)$ \\
Import*BE_M & $0.046^{* * *}$ & $0.056^{* * *}$ & $0.059^{* * *}$ & $0.063^{* * *}$ \\
& $(0.011)$ & $(0.009)$ & $(0.012)$ & $(0.011)$ \\
Controls & YES & YES & YES & YES \\
Export & & & & \\
Import & & & & \\
Exit_indicator & & & & \\
Entry_indicator & & & & \\
ind_comp & & & & \\
& & & & \\
\hline
\end{tabular}

Note: Huber White Standard errors in parentheses ${ }^{*} p<0.10,{ }^{* *} p<0.05,{ }^{* * *} p<0.01$ 
Another strategy would be to instrument the border effect with policy variables such as tariffs in order to keep only the (exogenous) information of trade policies. However, at the industry level we do not have too much variance for imports and for exports the data is only available from 1996 in the CEPII compilation. Moreover, as exposed above, the fact that trade policies have gone far beyond tariffs reduction arise the question about the potential missing information in this instrument.

\section{Conclusions}

This study addresses the effect of import and export oriented policies on the evolution of plant's productivity using Chilean data of manufacturing plants. To measure plant's TFP we estimate the production function of each two digit industry using a semiparametric methodology that takes into account the heterogeneity of productivity among firms. The main contribution of the paper is to construct an accurate measure of the outcome of trade liberalization at the industry level to disentangle the impact of the reduction of export and import barriers on plant productivity.

The incorporation of a more detailed measure of trade liberalization introduces two new results. First, the reduction of export barriers improves productivity of plants belonging to both export oriented and import competing sectors, relative to non traded sectors. As the export costs fall, more firms are able to export increasing their size and probably benefiting from knowledge spillovers arising from the foreign market.

Second, the reduction of import barriers shows a positive impact on the evolution of plant's productivity of export oriented sectors relative to non traded. However, this is not the case for plants competing with foreign exporters. It seems that the reduction of import barriers might hurt the benefits from increasing returns since it reduces the domestic share of local firms. This has consequence on policy implications. Trade policy should by rather focused on export oriented measures such as reinforcement of bilateral or multilateral trade agreements and reducing the fixed export costs of adapting the product to the new market.

To our point of view, further research should be oriented in two directions. Firstly, the possible endogeneity issue mentioned in the previous paragraphs 
should be completely tackled by means of good instruments for border effects such as policy indicators at the industry level for exporter and importers over the full sample period. Secondly, theoretical and empirical efforts should be focused on general equilibrium effects by which the consequences of specific oriented policies are transmitted to the rest of the economy. 


\section{References}

[1] Alvarez R. and Lopez R. (2005).Exporting and performance: evidence from Chilean plants, Canadian Journal of Economics, 38 (4), pp. 1384400.

[2] Anderson J. and Van Wincoop E. (2003).Trade costs, Journal of Economic Litera-ture, 42 (3), pp. 691-751.

[3] Andweler W. and Trefler D. (2002).Increasing returns and all that: a view from trade. Journal of Economic Perspectives, 6,1, 87-105.

[4] Aw B., Chung S. and Roberts M. (1999).Productivity and turnover in the export market: micro evidence from Taiwan and South Korea, Journal of Economic Litera-ture, 42 (3), pp. 691-751.

[5] Baldwin R. (1989).Sunk cost hysteresis, NBER Working Paper No. 2911.

[6] Bergoeing R., Hernando A. and Repetto A. (2006).Market reforms and efficiency gains in chile. Working Paper CEA, Universidad de Chile.

[7] Bergoeing R., Micco A. and Repetto A. (2005).Dissecting the chilean export boom. Working Paper CEA, Universidad de Chile.

[8] Bergstrand J. (1989). The generalized gravity equation, monopolistic competition, and the factor-proportions theory in international trade. The Review of Economics and Statistics, Vol. 71, No.1, 143-153.

[9] Bernard A., Eaton J., Jensen J. and Kortum S. (2000). Plants and productivity in international trade

[10] Bernard A. and Jensen J. (2001). Who dies? International Trade, market structure and industrial restructuring. NBER.

[11] Bernard A., Jensen J. and Schott P. (2003). Falling trade costs, heterogeneous firms and industry dynamics. NBER 
[12] Clerides K., Lach S., and Tybout J. (1998)Is learning by exporting important? micro-evidence from Colombia, Mexico and Morocco. The Quarterly Journal of Economics, 113, 903-947.

[13] Devarajan S. and Rodrik D. (1989), Trade liberalization in developing countries: do imperfect competition and scales economies matter?. The American Economic Review, 79, 2, 283-287.

[14] Dixit A. (1989), Exit and entry decisions under uncertainty, Journal of Political Economy, XCVII (1989), 620-638..

[15] Eaton J. and Kortum S. (2002). Technology, Geography and Trade

[16] Evans C. (2003).The Economic Significance of National Border Effects. The American Economic Review, Vol. 93, No. 4, 1291-1312.

[17] Feenstra R. (2003).Advanced International Trade: Theory and Evidence. Princeton University Press.

[18] Fontagne L., Mayer T. and Zignago S. (2005).Trade in the Triad: how easy is the access to large markets?. Canadian Journal of Economics, Vol. 38, No. 4, 1402-1430.

[19] Griliches Z. and Mairesse J. (1995). Production Functions: The Search for Identification. NBER Working Papers 5067

[20] Grossman G. and Helpman E. (1991).Innovation and Growth in the World Economy, Cambridge, MA: MIT Press.

[21] Hummels D. (2001).Toward a Geography of Trade Costs. Purdue University, mimeo.

[22] Irarrazabal A. and Opromolla D. (2006). Trade reforms ina global competition model: the case of Chile. New York University, mimeo.

[23] Katayama H., Lu S. and Tybout J. (2005) Firm-level productivity studies: illusions and a solution. Revue d'Economie du Developpement

[24] Kray (1999) Exportations et performances economiques: etude d'un panel d'entreprises chinoises. Revue d'Economie du Developpement 
[25] Koenker R. and Hallock K. (2001).Quantile Regression. Journal of Economic Perspectives, Vol 15, Number 4.

[26] Krugman P. (1989).Exchange Rate Instability. Cambridge, MA: MIT Press, 1989.

[27] Lane P. (2003).The New Open Economy Macroeconomics: a Survey. Journal of International Economics, vol. 54(2), pp 235-266.

[28] Levinsohn J. and Petrin A. (2003).estimating production functions using inputs to control for unobservables. Review of Economic Studies 70, 31741.

[29] Melitz M. (2003).The impact of Trade on Intra-Industry Reallocations and Agregate Industry Productivity.

[30] Olley S. and Pakes A.(1996).The dynamics of productivity in the telecommunication equipment industry. Econometrica 64, 1263-98.

[31] Pavcnik N. (2002).Trade liberalization, exit and productivity improvement: evidence from chilean plants. Review of Economic Studies, 69, $245-76$.

[32] Rodrik D. (1988).Imperfect competition, scale economies and trade policy in developing countries. In Baldwin R. ed., 'Trade policiy issues and empiricl analysis. Chicago and London: The University of Chicago Press, 1988a, 109-143.

[33] Rodrik D. (1992). The limits of trade policiy reform in developing countries. The American Economic Review, 92,1, 93-119. 


\section{CESifo Working Paper Series}

for full list see www.cesifo-group.org/wp

(address: Poschingerstr. 5, 81679 Munich, Germany, office@cesifo.de)

2012 Carlos Alós-Ferrer, Georg Kirchsteiger and Markus Walzl, On the Evolution of Market Institutions: The Platform Design Paradox, June 2007

2013 Axel Dreher and Martin Gassebner, Greasing the Wheels of Entrepreneurship? The Impact of Regulations and Corruption on Firm Entry, June 2007

2014 Dominique Demougin and Claude Fluet, Rules of Proof, Courts, and Incentives, June 2007

2015 Stefan Lachenmaier and Horst Rottmann, Effects of Innovation on Employment: A Dynamic Panel Analysis, June 2007

2016 Torsten Persson and Guido Tabellini, The Growth Effect of Democracy: Is it Heterogenous and how can it be Estimated?, June 2007

2017 Lorenz Blume, Jens Müller, Stefan Voigt and Carsten Wolf, The Economic Effects of Constitutions: Replicating - and Extending - Persson and Tabellini, June 2007

2018 Hartmut Egger and Gabriel Felbermayr, Endogenous Skill Formation and the Source Country Effects of International Labor Market Integration, June 2007

2019 Bruno Frey, Overprotected Politicians, June 2007

2020 Jan Thomas Martini, Rainer Niemann and Dirk Simons, Transfer Pricing or Formula Apportionment? Tax-Induced Distortions of Multinationals' Investment and Production Decisions, June 2007

2021 Andreas Bühn, Alexander Karmann and Friedrich Schneider, Size and Development of the Shadow Economy and of Do-it-yourself Activities in Germany, June 2007

2022 Michael Rauscher and Edward B. Barbier, Biodiversity and Geography, June 2007

2023 Gunther Schnabl, Exchange Rate Volatility and Growth in Emerging Europe and East Asia, June 2007

2024 Erkki Koskela and Ronnie Schöb, Tax Progression under Collective Wage Bargaining and Individual Effort Determination, June 2007

2025 Jay Pil Choi and Marcel Thum, The Economics of Politically Connected Firms, June 2007

2026 Jukka Pirttilä and Roope Uusitalo, Leaky Bucket in the Real World: Estimating Inequality Aversion Using Survey Data, June 2007 
2027 Ruslan Lukach, Peter M. Kort and Joseph Plasmans, Strategic R\&D with Knowledge Spillovers and Endogenous Time to Complete, June 2007

2028 Jarko Fidrmuc, Neil Foster and Johann Scharler, Labour Market Rigidities, Financial Integration and International Risk Sharing in the OECD, June 2007

2029 Bernardina Algieri and Thierry Bracke, Patterns of Current Account Adjustment Insights from Past Experience, June 2007

2030 Robert Dur and Hein Roelfsema, Social Exchange and Common Agency in Organizations, June 2007

2031 Alexander Libman and Lars P. Feld, Strategic Tax Collection and Fiscal Decentralisation: The Case of Russia, June 2007

2032 Øystein Foros, Hans Jarle Kind and Greg Shaffer, Resale Price Maintenance and Restrictions on Dominant Firm and Industry-Wide Adoption, June 2007

2033 Jan K. Brueckner and Kurt Van Dender, Atomistic Congestion Tolls at Concentrated Airports? Seeking a Unified View in the Internalization Debate, June 2007

2034 Viet Do and Ngo Van Long, International Outsourcing under Monopolistic Competition: Winners and Losers, June 2007

2035 Nadia Fiorino and Roberto Ricciuti, Determinants of Direct Democracy, June 2007

2036 Burkhard Heer and Alfred Maussner, Inflation and Output Dynamics in a Model with Labor Market Search and Capital Accumulation, June 2007

2037 Konstantinos Angelopoulos, Jim Malley and Apostolis Philippopoulos, Public Education Expenditure, Growth and Welfare, June 2007

2038 Maarten Bosker, Steven Brakman, Harry Garretsen and Marc Schramm, Adding Geography to the New Economic Geography, June 2007

2039 Steffen Henzel, Oliver Hülsewig, Eric Mayer and Timo Wollmershäuser, The Price Puzzle Revisited: Can the Cost Channel Explain a Rise in Inflation after a Monetary Policy Shock?, July 2007

2040 Rosario Crinò, Service Offshoring and White-Collar Employment, July 2007

2041 Carsten Hefeker and Michael Neugart, Labor Market Regulation and the Legal System, July 2007

2042 Bart Cockx and Muriel Dejemeppe, Is the Notification of Monitoring a Threat to the Unemployed? A Regression Discontinuity Approach, July 2007

2043 Alfons J. Weichenrieder, Profit Shifting in the EU: Evidence from Germany, July 2007 
2044 Annika Alexius and Bertil Holmlund, Monetary Policy and Swedish Unemployment Fluctuations, July 2007

2045 Axel Dreher, Jan-Egbert Sturm and Jakob de Haan, Does High Inflation Cause Central Bankers to Lose their Job? Evidence Based on a New Data Set, July 2007

2046 Guglielmo Maria Caporale and Luis A. Gil-Alana, Long Run and Cyclical Dynamics in the US Stock Market, July 2007

2047 Alessandro Balestrino, It is a Theft but not a Crime, July 2007

2048 Daniel Becker and Michael Rauscher, Fiscal Competition in Space and Time: An Endogenous-Growth Approach, July 2007

2049 Yannis M. Ioannides, Henry G. Overman, Esteban Rossi-Hansberg and Kurt Schmidheiny, The Effect of Information and Communication Technologies on Urban Structure, July 2007

2050 Hans-Werner Sinn, Please Bring me the New York Times - On the European Roots of Richard Abel Musgrave, July 2007

2051 Gunther Schnabl and Christian Danne, A Role Model for China? Exchange Rate Flexibility and Monetary Policy in Japan, July 2007

2052 Joseph Plasmans, Jorge Fornero and Tomasz Michalak, A Microfounded Sectoral Model for Open Economies, July 2007

2053 Vesa Kanniainen and Panu Poutvaara, Imperfect Transmission of Tacit Knowledge and other Barriers to Entrepreneurship, July 2007

2054 Marko Koethenbuerger, Federal Tax-Transfer Policy and Intergovernmental PreCommitment, July 2007

2055 Hendrik Jürges and Kerstin Schneider, What Can Go Wrong Will Go Wrong: Birthday Effects and Early Tracking in the German School System, July 2007

2056 Bahram Pesaran and M. Hashem Pesaran, Modelling Volatilities and Conditional Correlations in Futures Markets with a Multivariate t Distribution, July 2007

2057 Walter H. Fisher and Christian Keuschnigg, Pension Reform and Labor Market Incentives, July 2007

2058 Martin Altemeyer-Bartscher, Dirk T. G. Rübbelke and Eytan Sheshinski, Policies to Internalize Reciprocal International Spillovers, July 2007

2059 Kurt R. Brekke, Astrid L. Grasdal and Tor Helge Holmås, Regulation and Pricing of Pharmaceuticals: Reference Pricing or Price Cap Regulation?, July 2007

2060 Tigran Poghosyan and Jakob de Haan, Interest Rate Linkages in EMU Countries: A Rolling Threshold Vector Error-Correction Approach, July 2007 
2061 Robert Dur and Klaas Staal, Local Public Good Provision, Municipal Consolidation, and National Transfers, July 2007

2062 Helge Berger and Anika Holler, What Determines Fiscal Policy? Evidence from German States, July 2007

2063 Ernesto Reuben and Arno Riedl, Public Goods Provision and Sanctioning in Privileged Groups, July 2007

2064 Jan Hanousek, Dana Hajkova and Randall K. Filer, A Rise by Any Other Name? Sensitivity of Growth Regressions to Data Source, July 2007

2065 Yin-Wong Cheung and Xing Wang Qian, Hoarding of International Reserves: Mrs Machlup's Wardrobe and the Joneses, July 2007

2066 Sheilagh Ogilvie, 'Whatever Is, Is Right'?, Economic Institutions in Pre-Industrial Europe (Tawney Lecture 2006), August 2007

2067 Floriana Cerniglia and Laura Pagani, The European Union and the Member States: Which Level of Government Should Do what? An Empirical Analysis of Europeans' Preferences, August 2007

2068 Alessandro Balestrino and Cinzia Ciardi, Social Norms, Cognitive Dissonance and the Timing of Marriage, August 2007

2069 Massimo Bordignon, Exit and Voice. Yardstick versus Fiscal Competition across Governments, August 2007

2070 Emily Blanchard and Gerald Willmann, Political Stasis or Protectionist Rut? Policy Mechanisms for Trade Reform in a Democracy, August 2007

2071 Maarten Bosker and Harry Garretsen, Trade Costs, Market Access and Economic Geography: Why the Empirical Specification of Trade Costs Matters, August 2007

2072 Marco Runkel and Guttorm Schjelderup, The Choice of Apportionment Factors under Formula Apportionment, August 2007

2073 Jay Pil Choi, Tying in Two-Sided Markets with Multi-Homing, August 2007

2074 Marcella Nicolini, Institutions and Offshoring Decision, August 2007

2075 Rainer Niemann, The Impact of Tax Uncertainty on Irreversible Investment, August 2007

2076 Nikitas Konstantinidis, Gradualism and Uncertainty in International Union Formation, August 2007

2077 Maria Bas and Ivan Ledezma, Market Access and the Evolution of within Plant Productivity in Chile, August 2007 